\title{
SOCIOLOGICAL AND THEOLOGICAL FACTORS THAT CAUSED SCHISMS IN THE APOSTOLIC FAITH MISSION OF SOUTH AFRICA
}

\section{Mookgo Solomon Kgatle ${ }^{1}$}

University of Pretoria

kgatles@yahoo.com

\section{ABSTRACT}

The Apostolic Faith Mission (AFM) of South Africa has experienced schisms from the year 1910 to 1958 . The schisms were caused by sociological and theological factors. These are schisms by the Zionist churches (Zion Apostolic Church, Christian Catholic Apostolic Holy Spirit Church in Zion, Zion Apostolic Faith Mission); Latter Rain; Saint John Apostolic Faith Mission and Protestant Pentecostal Church. The sociological factors that led to the schisms by the Zionist churches and the Protestant Pentecostal Church are identified as racial segregation and involvement in politics respectively. The theological factors that caused these schisms by Latter Rain and Saint John Apostolic Faith Mission are manifestations of the Holy Spirit and divine healing respectively. After comparison of the factors, it is concluded that racial segregation is the main factor that caused schisms in the AFM.

Keywords: Apostolic Faith Mission; schisms; racial segregation; divine healing; Holy Spirit

1 Mookgo Solomon Kgatle is a $\mathrm{PhD}$ (New Testament) graduate and research associate at the Department of New Testament Studies, University of Pretoria. This article flows from his PhD thesis titled Servant leadership in Mark 10:35-45 applied to African Pentecostal Christianity, completed under the supervision of Prof. Dr Ernest van Eck.

\section{UNISA $\cong$}




\section{INTRODUCTION}

The Apostolic Faith Mission (AFM) is an African Pentecostal Christian church founded by American missionaries, John G Lake and Thomas Hezmalhach in 1908. The departure of John G Lake and Thomas Hezmalhach from South Africa to the United States caused problems to arise in the early developments of the AFM. These problems resulted in the schisms that took place in the AFM. These schisms were caused by various social and theological factors. The purpose of this article is to discuss such factors, making comparisons and reaching a conclusion on the factors.

The AFM has suffered many schisms since its early stages. Research on the history of the AFM shows that many of these schisms were never recorded in the church. These are schisms that came from the Zionist churches associated with P.L. le Roux (one of the prominent leaders of the AFM with a Zionist background) and black pastors. This article is an attempt to highlight and recognise these schisms and the factors that caused them. In addition, the article endeavours to contribute to the ongoing research on other schisms like the Latter Rain, Saint John Apostolic Faith Mission and Protestant Pentecostal Church.

These schisms should not be underestimated as they impacted negatively on the AFM in particular and the Pentecostal Movement in South Africa at large; on the AFM in the sense that the church would have grown much larger in number than the status quo had it not been for these schisms; on the Pentecostal Movement in the sense that the AFM has lost an opportunity to be the largest Christian church in southern Africa with a Pentecostal influence. At present the largest Christian church in southern Africa is the Zion Christian Church, which has lost the message and fundamental teachings of Pentecost. These types of churches exist mainly as a result of schisms that occurred in the AFM.

This article discusses the following social and theological factors:

- Racial segregation.

- Involvement in politics.

- Manifestation of the Holy Spirit.

- Divine healing.

\section{SCHISMS IN THE APOSTOLIC FAITH MISSION OF SOUTH AFRICA: 1910-1958}

\section{The 1910 Christian Catholic Apostolic Holy Spirit Church in Zion schism}

Whilst some of the Zionist congregation eventually followed Le Roux into the AFM, Daniel Nkonyane and 56 other people used their relative autonomy and the low- 
key links they had with the AFM to develop their own Zionist followers. Nkonyane therefore founded the Christian Catholic Apostolic Holy Spirit Church in Zion. These leaders developed Africanised versions of Pentecostalism very different in form and intent from the original American packages. These Africanised versions were demonstrated through divine healing and liturgy (Maxwell 1999, 250).

In the years between 1912 and 1920 Nkonyane, the most impressive among the early Zion leaders, introduced certain elements into worship which have remained visible hallmarks of Zionism to this day: white robes, bare feet, holy sticks, and Old Testament symbolism. These elements were taught and practised by John Alexander Dowie. Le Roux and other white Pentecostals objected to the use of such symbols. As a result Nkonyane broke away from the AFM to initiate the Christian Catholic Apostolic Holy Spirit Church in Zion (Roy 2000, 113).

Another view is that racial segregation contributed to the many schisms that took place by the Zionists. Two of the Zulu leaders associated with Le Roux were Nkonyane and Fred Luthuli, both of whom already had hundreds of followers of their own by 1905 and were to establish a significant number of African Independent Zionist Churches after breaking with the AFM from 1910 onwards. Nkonyane broke with the AFM in 1910, eventually forming the Christian Catholic Apostolic Holy Spirit Church in Zion (Anderson 2008, 28).

Nkonyane took over the leadership in the Zionist congregation. He had worked alongside Le Roux from 1890. He looked for a white leader to take Le Roux's place. Edgar Mahon, formerly a captain in the Salvation Army, baptised by Büchler, served for a short while in that congregation. He bought land for Nkonyane's work at Charlestown and Nkonyane changed the name of his church to the Christian Catholic Apostolic Holy Spirit Church in Zion. The AFM took Nkonyane's ordination certificate away because he left the church (Nel 2005, 139).

As Le Roux became increasingly involved in the activities of the AFM, Nkonyane, presumably one of the most trusted co-workers, started emerging as an outstanding leader of the Zionists (Khathide 2010, 46). He had been with Le Roux ever since the latter's Dutch Reformed days in the 1890s and was himself originally a member of the Dutch Reformed mission. Nkonyane and his wife shared Le Roux's experiences. When Nkonyane was dismissed as a leader, he founded the Christian Catholic Apostolic Holy Spirit Church in Zion.

\section{The 1917 Zion Apostolic Church schism}

Elias Mahlangu, as an AFM preacher, did not break with the white Pentecostals until about 1917. He then left to establish the Zion Apostolic Church of South Africa, one of the earliest of many secessions from the AFM (Anderson 1999, 288). Prior to the schism the AFM regarded this congregation as its Zion branch. There was a gradual estrangement which occurred between the AFM and its Zionist branch, that ultimately resulted in the breakaway by this branch (Roy 2000, 113). This would 
suggest that the Zion Apostolic Church and Mahlangu were a part of the AFM for a long time until the departure of Le Roux. Le Roux had to leave Wakkerstroom for Johannesburg and the mother assembly because he was elected as president.

On 8 December 1915 a special meeting was arranged to discuss the fusing of the AFM with the Zion Apostolic Church. After voting, the Zion Apostolic Church decided against working with the AFM. At a Workers' Conference a few of the workers who had come out of the Zionist movement testified why they had left the Zionists. ${ }^{2}$ The proposal that the AFM would not have any fellowship with the Zionist movement was accepted (Burger and Nel 2008, 246).

\section{The 1921 Zion Apostolic Faith Mission schism}

Edward Motaung (also known as Edward Lion) the founder of the Zion Apostolic Faith Mission, was at first a preacher in the AFM as he joined the church in 1912 and was given oversight of the work in Lesotho. The reasons for the breakaway with the church are not that clear, but it is assumed that he became involved in heretical teaching and prophecies which resulted in him being discredited. Nevertheless, he was one of the first early Pentecostals with the intent of founding a 'City of Zion' in Lesotho similar to the one of John Alexander Dowie in Chicago. It seems that the dream was fulfilled because he also influenced Engenas Lekganyane, the founder of Zion Christian Church and Zion City Moriah (see Anderson 1992, 41).

Maxwell $(1999,250)$ explains that prior to the South African Pentecost, Lion had cultivated links with white Zionist, Mahon, but from 1910 to 1919 he maintained relations with the AFM. Lion was considered AFM Overseer for Basutoland and his delegates attended the 1918 Native Conference. He went his own way again in 1921, printing his own identification cards which bore a remarkable resemblance to the one previously issued to him by the AFM.

To sum up, Burger and Nel $(2008,205)$ states that the father of Sotho-Zionism was Motaung. He had a charismatic ministry with a large number of followers in Basutoland. When the first AFM workers arrived in Basutoland in 1912, they met with Motaung, who was already working on his own for a number of years, disseminating a form of Zionism. After negotiations, Motaung joined the AFM and renamed his church the 'Zion Apostolic Faith Mission'. In 1914 the AFM had problems with Motaung because of lack of submission, and in 1921 the final break came which did a lot of harm to the AFM in Lesotho.

\section{The 1928 Latter Rain group schism}

The Latter Rain group in South Africa was not in any way connected with the wellknown international Latter Rain Churches, but had sought similar manifestations 
and emphasis to the known Latter Rain Churches at large. These comprise rigorous bodily participation, mutual in both worship and in use of the gifts of the Spirit; liturgical dance; stress on private revelation in spite of inconsistency with scripture; emphasis on sins and their revelation; atypical forms of clothing; prophesying; and firm individual and authoritarian leadership (Chandomba 2007, 32).

The Latter Rain group in South Africa came about as a result of a split that happened in the AFM. According to Burger and Nel $(2008,107)$, this was one of the most unfortunate episodes in the early history of the AFM. It started with Maria Fraser, who joined the church in Benoni, in 1920. After a few years she developed the conviction that the church was spiritually 'cooling down' and that sins were on the increase. She firmly believed that a worldly inclination was taking over in the church. She alleged that this placed a damper on the free operation of spiritual gifts.

Burger and Nel $(2008,108)$ continues to say that starting in March 1927, 10 women, led by Fraser, met daily at 10:00 in the AFM's hall in Benoni. They often fasted. In those prayer meetings the spiritual gifts were emphasised. They stressed the role of visions and revelations by means of which secret matters, and especially sins, were revealed by means of prophecy. Fraser $(1969,110)$ adds that the group went for control of the church hall. They had the set of keys and to make their 'occupation' complete, the women prayed there by day and men through the night.

The Executive Council took a decision that they were to consider themselves no longer members of the mission, and they forwarded the names of those members of the assembly who were standing with them, to headquarters. ${ }^{3}$ This decision was not taken before the Executive Council had given the group ample opportunity to retain their AFM membership, on the condition that they drop the idea of uniform clothing; abandon their judgmental spirit of 'revealing sins' to the Holy Spirit; hand over the keys to the church hall; and stop the printing and publishing of a newsletter titled 'Benoni Latter Rain Messenger' (Burger and Nel 2008, 110).

The group of 30 persons still refused to vacate the hall or to hand over the keys. On 18 January 1928, a final attempt at reconciliation was made, but the rebels refused to meet the Executive and still blocked entry to the building. The Executive Council then decided to sell the hall to the 'Church of Christ' for R1400. ${ }^{4}$ The money was then made available to the Benoni congregation for the purchase of alternative accommodation. The Latter Rain group was forced to abandon the hall. ${ }^{5}$

\section{The 1938 Saint John Apostolic Faith Mission schism}

Christina Nku was a member and a minister of the AFM. When Le Roux objected to some of her more elaborate displays of prophetic rapture, she left to start the Saint

3 Minutes of the Executive Council, 8 December 1927, Book 4, 1000-1002.

4 Minutes of the Executive Council, 8 December 1927, Book 4, 1009-1010.

5 Minutes of the Executive Council, 8 December 1927, Book 4, 1011-1012. 
John Apostolic Faith Mission. She also had a vision of a big church with 12 doors and she was told to follow the baptism of John and Jesus. She had another vision in which she was shown the exact place where she was to build the church near Evaton in Johannesburg. Nku became famous as a faith healer and prayed for bottles and buckets of water which were used for healing. These practices soon distanced Nku from the Pentecostal Movement (Anderson 1992, 106). The church began in 1938 when its black female founder, Mother Christina Nku, received a vision from God to establish the church (Thomas 1997, 13). Since then, branches of the church have spread throughout southern Africa.

Nku was a pioneer, one of a few women who initiated independent African churches. She also followed a stream of Africans who grew tired of being dominated by white Protestant Christianity and separated from mission churches to create new religious cosmologies that blended Christian symbols and practices into wellestablished pre-colonial religious systems (Thomas 1999:5).

$\mathrm{Nku}$, who took the title 'Founder and General President' of the Saint John Apostolic Faith Mission, became well-known as a person of prayer with healing power. She gathered thousands into her church. It was particularly her practices, however, that brought increasing distance between her and the AFM (Roy 2000, 118). In 1906, at Derdepoort (Botswana), a 12-year old Tswana girl, Nku, experienced the first of a series of divine visions that eventually led to the founding of a powerful African independent church under the name Saint John Apostolic Faith Mission (Landman 2006, 1).

In addition, Saint John Apostolic Faith Mission is a type of an African independent church that is relevant to divine healing and deliverance. Saint John Apostolic Faith Mission and all its splinter groups can be theorised as presenting a crisis model for managing change (Masondo 2013, 157). These churches provide their members with a well worked out path of inclusion through baptism and related rituals, as well as alleviation of crisis through an assortment of healing, cleansing and deliverance rituals.

\section{The 1958 Protestant Pentecostal Church schism}

The AFM underwent major upheaval in the 1950s over what was perceived as open support of the Nationalist government. In 1956 it permitted its vice-president, G.R. Wessels, to accept a Nationalist government nominated seat in the South African Senate. This move inaugurated a major split in the church when, after bitter controversy, twelve AFM ministers and several of their members seceded to launch a new denomination, the Pentecostal Protestant Church (Pillay 1987, 47).

This appointment of Wessels was not the only reason for the 1958 schism. Chandomba $(2007,36)$ identifies the well-known healing evangelists William Branham and Oral Roberts's tour to South Africa in 1951. With their great and touching services, their tour aroused a passion amid countless others for a more 
extrovert Pentecostal liturgy. The miraculous gifts of the Spirit would manifest throughout their services, demonstrating the power and the Spirit. These components blended to bring about a division of the AFM membership into two factions. The first faction was an old order faction, and also a new order faction within the AFM.

The other cause of the Protestant Pentecostal Church schism was competition for position, especially in the white Executive Council. Burger and Nel (2008, 160) cite one example of such jogging for positions, which also resulted in unrest and schism in the church in 1958. The person referred to in this case is Pastor J.H. Snyman, the main character and soul of the schism as a result of personal vendetta and competition for senior posts. He is said to have had ambitions of becoming the General Secretary of the church, and when he was not chosen for the post, he started the schism.

\section{SOCIOLOGICAL FACTORS THAT CAUSED THE SCHISMS}

\section{Racial segregation}

In the schisms by the Zionist churches, racial segregation policy of the AFM caused many black pastors to leave the church. Black pastors expected to be offered financial support, given their financial difficulties. When the AFM Executive Council could not fulfil their desires, the black pastors left the church (Hollenweger 1972, 102). Consequently, racial segregation caused the proliferation of African Independent Churches, mostly Zionist churches. To illustrate this point, when Le Roux was elected as president and had to leave for the mother assembly, it alienated black pastors. They would not follow him to the AFM because of fear of racial discrimination (Poewe 1988, 148).

In the beginning the name 'Zion' was used to refer to the Zion branch of the AFM. The Zion Apostolic Church schism occurred because Le Roux, the leader of the 'Zion' branch of the AFM at that time, was spending much of his time and energy in the AFM mother assembly in Doornfontein, Johannesburg. Consequently, he could not concentrate on the work of the 'Zion' branch of the AFM. Le Roux was therefore advised to resign and black pastors emerged in this period to start their own independent churches (De Wet 1989, 34).

Le Roux's neglect of the 'Zion' branch was not the only reason for the schism. On the contrary, the black leaders stayed loyal to their Zionist roots because of its affinities to their African culture and they remained with the AFM even after his departure. This decision was taken on the understanding that they would be permitted to carry on their work independently and indigenise the AFM. When this was not possible under the white Executive Council of the AFM, black pastors seceded to form the Zionist churches (Erasmus 1996, 34). 
Equally important was the strong domination by the 'whites' who enforced Westernised thinking on Africans without their consent. The white section of the AFM was a supreme section because white missionaries served as chairpersons of all councils of non-white churches. The other sections of the church were just objects in the church, as they could not take part in the decision-making body of the church. When the black pastors could not find a solution to this problem, they opted for splits.

The African church continued to work together with the AFM. As AFM whites discriminated against blacks (because of their loyalty to racial segregation that was a practice in South Africa and because they kept all significant leadership positions within their ranks) the African Zionist leaders seceded to start their own churches (Anderson 2008, 28). This contributed to the many schisms that took place thereafter by the Zionist churches. Consequently, a significant number of African Independent Zionist Churches were established after breaking with the AFM from 1910 onwards.

After their freedom from the oppressor, Zionist churches adopted a style of liturgy that made it easy for dreams, visions, prophecies, dancing and relevant praise songs to take place in their services. This kind of freedom no doubt contributed to the rapid growth of the Zionist churches. It caused the Zionist churches to be established as indigenous churches in South Africa. The message was relevant to the needs of the audience and everyone who listened to them. It was indeed this type of growth that further alienated the Zionist churches from the Pentecostal movement in South Africa.

The schism was not necessarily centred on individual reasons but based on fundamental differences between Zion and Pentecost. It could be the gradual estrangement which occurred between the Pentecostals and the Zionists that ultimately resulted in the breakaway by the Zionist churches (Roy 2000, 113; cf. Khathide 2010, 49). The estrangement was caused by racial discrimination and white supremacy. The institutionalised racism ensured that black people remained marginalised and oppressed.

Moreover, South African history reveals that the macro-structures, such as the AFM during racial segregation, developed to give advantages to white South Africans. Consequently, they guaranteed the underdevelopment of African, Asian and coloured communities in South Africa. These macro-structures were biased. They are also a direct outgrowth of the culture and history which white South Africans brought with them from their European origins (Thomas 1997, 13).

Poor black Africans have developed a new liturgy to reorient, and, in a sense, reinvent their social reality. Poor black pastors of the AFM broke away from the macro-structure to be relevant to their own people. They were not included in the economy of the country at that time and felt a need to be independent. They did not mind to break away from the macro-structure if that structure did not beneficiate them. They sacrificed the little that they received in the macro-structure and started their own ministries. 
The black pastors played a very significant role in giving the 'Pentecostal Movement' in South Africa an African character. They attempted to contextualise Christianity, making it relevant to everyday life, especially through the use of practical ritual techniques which are not found in mission churches. It is also interesting to note that all these leaders were coming from "the lower social strata, while their counter-parts in the Western-oriented churches were from the 'middle class'. These leaders were able to initiate and develop, consciously and unconsciously, African Christian Theology (Moripe 1996:30).

African leadership was not given space to emerge and function. This eventually resulted in secessions of independent Zionist and Apostolic churches, and increasing distance between black and white Pentecostals in the same denomination. The secessions from the AFM marked the beginning of the independent African Pentecostal churches, which mushroomed from some 30 churches in 1913 to 3000 by 1970, and over 6000 by 1990 (Anderson 2001, 3).

In the AFM not only did the Executive Council take decisions on behalf of the black section of the church, but also missionaries were appointed to oversee black churches. This factor discouraged many black pastors who were ready to work in the AFM; as a result they started their own churches. It was not necessarily a black and white issue but the fact that the appointed white pastors could not be relevant to the needs of the African people. Hence, after a breakaway, the Zionist churches attracted more people in their gathering.

The black pastors who had joined the AFM eventually found themselves estranged from the decision-making of the church, since most of the converts among the whites were Afrikaners. These so-called 'poor whites' found themselves in economic competition with blacks, particularly in the urban setting, and tensions were not long in developing. In 1919 a large group of black members withdrew from the AFM (Clark 2005, 144).

Racial segregation played a major role in the breaking away of the black Zionists to launch their own organisation. The open support of the apartheid policies in South Africa by the white leadership of the AFM led to much destruction of the relationship between the black and white members of the AFM, from which both groups needed liberation (Chandomba 2007, 33). This refers to especially leaders who were in the Zionist movement led by Le Roux. These leaders could not stand to be side-lined from the tasks they were accustomed to. For many black leaders, to leave the AFM served as their mechanism for protesting the racially divisive policies implemented by the leadership of the AFM (Richardson 2013, 30).

It was also a means to protest against the theological and political positions that the institutional church took on the issues of the day. For others, continued participation in the AFM, combined with engagement in the struggle for racial equality through a variety of means, was the approach that they chose to take. Some decided to stay. They did so because they perceived their silence as humility and obedience to God. 


\section{Involvement in politics}

The election of Wessels as a Nationalist senator in 1955 was both politically and spiritually controversial. From a spiritual perspective it was an extraordinary decision by the AFM to allow a pastor to become a politician while keeping his pastoral credentials and staying on as vice-president. From a political point of view it meant that the AFM as the church supported the political ideologies of the National Party, especially ideologies of racial segregation (Horn 1991, 7). In both perspectives, it is a sign that the members of the AFM were not treated equally. Some were permitted to take part in politics while others were prohibited to do so. Rules and constitution of the AFM could be changed to suit one section of the church.

This move came as a surprise because at the 1956 Workers' Council of the AFM, a motion stated that no full-time worker should be actively involved in party politics. Wessels, the vice-president of the church at that time, held on to the position until 1970, when he decided to retire from ministry and relinquished this powerful position. This resulted in heavy internal fights in the church and eventually culminated in the schism of the Pentecostal Protestant Church (Lapoorta 1996, 69). The white church also discouraged blacks from being involved in politics or voicing their political beliefs. In other words, it was acceptable for a white pastor to be involved in politics, but unacceptable for a black pastor to take part in political activities (Matika 2004, 71).

It was positive because it led to the church being allowed to register as a religious denomination (as opposed to its registration under the Companies Act in 1908) with all the benefits it brought to its public ministry. The benefits included access to the state-controlled airwaves, entrance to a ministry in the security forces, hospitals and prisons as chaplains and lay-workers (Clark 2007, 46). The AFM aligned itself with the politics of the Nationalist government. This led to the disappointment of a large number of its members. The church sought for recognition and social standing on par with the other Afrikaner church organisations within the country (Richardson 2013, 50).

\section{THEOLOGICAL FACTORS THAT CAUSED THE SCHISMS}

\section{Manifestation of the Holy Spirit}

In 1927 Fraser prophesied a new outpouring of the Holy Spirit within the AFM. During the following nine months Fraser's followers experienced times of heavenly ecstasy with singing in tongues, holy dancing, laughing in the Spirit and visions of angels (Roy 2000, 112). The AFM leadership reacted strongly to what they regarded as the strange behaviour and unfair criticism of Fraser and her followers, who were eventually expelled from the church. 
The reason for the expulsion was that Fraser led a large number of AFM members into conflict with the church officials on the issue of Holy Spirit-inspired prophecy. Eventually the conflict led to a schism in which the Latter Rain movement found its expression in South Africa in 1928. The single positive contribution of Fraser to the AFM was an awakened re-emphasis upon the work; the presence of the Holy Spirit in church and ministry, together with the caution that such work and presence can never be assumed (as the Latter Rain people were assuming) outside of the parameters spelled out in the scriptures (Clark 2007, 45).

It is surprising that the AFM parted ways with Fraser because of the manifestation of the Holy Spirit. On the contrary, the manifestation of the Holy Spirit is the core of the Pentecostal-charismatic Christianity (Beckmann 1974, 11). The same manifestations of the Holy Spirit happened on the day of Pentecost in the book of Acts. It is recorded in Acts 2:1-4 that when the day of Pentecost fully arrived, they were all with one accord in one place. Suddenly there came a sound from heaven like a rushing mighty wind, and it filled the entire house where they were sitting. There appeared unto them cloven tongues as if on fire, and it sat upon each of them. They were all filled with the Holy Spirit, and began to speak with other tongues, as the Spirit gave them utterance (Acts 2:1-4).

These manifestations also found their way in the Azusa Street Revival. ${ }^{6}$ There were prostrations, strong crying unto God, weeping and manifestations of joy. Most notable of all, those who were filled with the Holy Spirit experienced physical manipulation of face and body and the final exercise of speaking in tongues as the Spirit of God gave utterance (McDonnell 1996, 610).

At the Azusa Street Revival a more symbolic correlation began to emerge alongside their more inclusive understanding of the results of Spirit baptism. The ability to speak in tongues was understood as an avenue of praise to God that symbolised the heavenly praise that would soon be instituted in the rapture. The idea of tongues as a private prayer language, also began to emerge in the Apostolic Faith as a symbol of a direct communion with God - reminiscent of Parham's notion of 'the anointing that abides'. Speaking in tongues was increasingly seen as an experience that in different ways symbolised the many varied blessings and benefits of Spirit baptism testified to by people at Azusa Street (Friesen 2009, 52).

The 1928 Latter Rain schism could have been avoided in the AFM. Perhaps the AFM Executive Council should have guided Fraser and her congregation in Benoni against extreme and unusual manifestations of the Holy Spirit. The AFM's Spiritual

6 The Azusa Street Revival is a Pentecostal revival meeting that happened in 1906 in the United States of America, Los Angeles. The revival, which was led by an African American, William J Seymour, was characterised by Spirit baptism with the evidence of speaking in tongues, miracles and other spiritual experiences. The revival attracted people in the United States of America and all over the world. The Azusa Street Revival lasted for more than eight years from 1906 until 1915. The Azusa Street Revival had an influence in the AFM through John G Lake, who had had contact with William J Seymour prior to coming to South Africa (Roy 2000:121.) 
Committee should have also guided Fraser on when and how such manifestation should take place. Instead, the Executive Council became too judgemental and this resulted in a schism.

\section{Divine healing}

In $1936 \mathrm{Nku}$ went to Evaton and started healing people. She did not want to ask them for payment, but eventually people started paying her a shilling (10c) so that she could feed her children (Landman 2006, 12). Landman continues to say that Nku did her healing through prayer and by dispensing the indigenous wisdom that she received through visions. The only 'ancillary' to her healing were the bottles of water she blessed and thus, this water acquired healing powers. Nku expanded her healing ministry with love towards other people and the advocacy of a healthy moral lifestyle (Landman 2006:16). Her church was a place for those who are ill and no one goes there willingly but through a special calling. Healing, through the use of holy water, was central to the theology and practice of the church (Masondo 2013, 163).

Nku adopted the use of water, among other natural resources, to facilitate the completion of respective procedures and processes such as baptism and cleansing. One of the reasons for the use of water in the church is that it was and continues to be regarded as sacred in the Apostolic tradition. Nku also used water to facilitate the completion of divine healing (Kunnie 1992, 6). The purpose of going into and using these sources was mainly to wash themselves in water in the belief that their wounds would be healed, pains eased and so forth. During those times, diseases were thought to be a sign of divine wrath. Washing and bathing in sacred waters was seen as serving a dual function, namely that of serving a rite of placating the gods and as a means of healing and curing the body (Lebeloane and Mokhele 2006, 147).

It was the use of these substances in divine healing that caused Nku to separate with the AFM (Anderson 1992, 106). It is astounding because John G Lake, the founder of the AFM, believed and practised divine healing. Lake is regarded as the 'Grandfather of the Healing Rooms Movement' (Poloma 2006, 61). Furthermore, Lake preached the message of divine healing and the Leviticus style taboos on alcohol and pork (Maxwell 1999, 251). For the early $20^{\text {th }}$ century, Lake had remarkable insight into the cause and healing of various forms of illness. He acted responsibly in his healing ministry. His philosophy about healing was simply that the praying for the sick person must continue until the person was healed (Burger and Nel 2008, 38).

The only difference between Lake and Nku's practice of divine healing is the use of substances. It is probable that Nku used substances and indigenous knowledge not to undermine the AFM, but to be relevant to African people and their context. The AFM should have accommodated and regulated these practices, but instead they shut them down. 


\section{COMPARISON OF THE FACTORS}

It has been discussed already that the practice of racial segregation is a factor that caused the schisms in the Zionist churches. Since Le Roux left the Zionist branch movement and concentrated more on the mother assembly, most black pastors felt neglected and alienated from the Pentecostal movement. Black pastors did not have the same opportunities as opposed to their white counterparts. They never had an opportunity to participate in leadership position. On the contrary, white pastors were appointed to oversee the work of black people.

The executive leadership of the AFM at that time supported racial policies of the Nationalist Party that ensured a white privilege. These policies were designed to segregate the society and divide the black people. It was these policies that caused the blacks to lose their land. These societal factors affected most of the black pastors. As a result they seceded and started their own ministries, which flourished under difficult circumstances.

Racial segregation also played a role in the schism by the Protestant Pentecostal Church, because all the factors and circumstances that led to this schism were racially motivated. The political involvement as a factor that caused this schism was racially motivated. The appointment of Wessels to the National Party senate was racially motivated in the sense that it alienated non-Afrikaner members of the AFM.

Many members of the church left as they were opposed to pastor Wessels's participation in politics. Racial segregation is also seen in the difference between the Old Order that accepted the humanistic manifestation of the Holy Spirit, and the New Order that rejected the humanistic manifestation of the Holy Spirit in the AFM. An attack on the Old Order in the AFM was an attack on blacks because most of their congregations were very humanistic in their liturgy.

It was not only manifestation of Holy Spirit and divine healing that contributed to the schisms by both the Latter Rain group and Saint John Apostolic Faith Mission respectively. Considering the fact that the founders of these schisms were both black, it is possible that race also played a role in these schisms. The humanistic manifestation of the Holy Spirit was not a strong case enough for the expulsion of Fraser in particular.

\section{CONCLUSION}

The schisms that occurred in the history of the AFM are: the 1917 Zion Apostolic Church; the 1910 Christian Catholic Apostolic Holy Spirit Church in Zion; the 1921 Zion Apostolic Faith Mission; the 1928 Latter Rain; the 1938 Saint John Apostolic Faith Mission; and the 1958 Protestant Pentecostal Church. The social factors that led to these schisms by the Zionist churches and the Protestant Pentecostal Church are identified as racial segregation and involvement in politics respectively. The theological factors that caused these schisms by Latter Rain and Saint John Apostolic 
Faith Mission, are manifestations of the Holy Spirit and divine healing respectively. When these factors are compared, it is found that racial segregation is the main factor that caused schisms in the AFM of South Africa.

\section{REFERENCES}

Anderson, A. 1992. Bazalwane: The African Pentecostals in South Africa. Pretoria: Unisa.

Anderson, A. 1999.The Lekganyanes and prophecy in the Zion Christian Church.Journal of Religion in Africa 29(3): 285-312.

Anderson, A. 2001. Pentecostals and apartheid in South Africa during ninety years 1908-1998. Cyberjournalfor Pentecostal-charismatic Research.http://www.pctii.org.cyberj/index.html (accessed on 1 March 2015).

Anderson, A. 2008. African independent churches and Pentecostalism: Historical connections and common identity. Ogbomoso Journal of Theology 13(1): 22-42.

Beckmann, D.M. 1974. From Africa to Pentecostalism. CTM 45(1): 11-26.

Burger, I. and Nel, M. 2008. The fire falls in Africa. Vereeniging: Christian Art.

Chandomba, L. 2007. The history of the Apostolic Faith Mission and other Pentecostal missionsin South Africa. Milton Keynes: Authorhouse.

Clark, M. 2005. Two contrasting models of missions in South Africa: The Apostolic Faith Mission and the Assemblies of God.Asian Journal of Pentecostal Studies8(1): 143-161.

Clark, M. 2007. Contemporary Pentecostal leadership: The Apostolic Faith Mission of South Africa.Asian Journal of Pentecostal Studies 10(1): 42-61.

De Wet, C.R. 1989. The Apostolic Faith Mission in Africa: 1908-1980. A case study in church growth in a segregated society.Unpublished $\mathrm{PhD}$ thesis.University of Cape Town.

Erasmus, L.J. 1996. Theological education in the Apostolic Faith Mission of South Africa, Unpublished $\mathrm{PhD}$ thesis. Pretoria: Unisa.

Fraser, M.M. 1969. Getuienis van geestelike groei, van geloofslewe en van werkinge van die Heilige Gees. Benoni.

Friesen, A. 2009. The called out of the called out: Charles Parham's doctrine of Spirit Baptism. Journal of the European Pentecostal Theological Association, 42-54.

Khathide, A.G. 2010. HambaVangeli Elisha: A portrait of Rev Job Y Chiliza- pioneer of the African Gospel Church. Kempton Park: Acad SA.

Hollenweger, W.J. 1972. The Pentecostals. London: SCM Press.

Horn, N. 1991. Crossing racial borders in Southern Africa:A lesson from history.Cyberjournal for Pentecostal-charismatic Research, http://www.pctii.org.cyberj/index.html (accessed on 1 March 2015).

Kunnie, J. 1992. Indigenous African Churches and religio-cultural liberation: The practice of traditional healing. Unpublished paper presented at the Thirty-Fifth Annual Meeting of the African Studies Association, Seattle, Washington.

Landman, C. 2006. Christina Nku and St John's: A hundred years later. Studia Historicae Ecclesiasticae 32(1): 1-32. 
Lapoorta, J.J. 1996. Unity or division? The unity struggle of the black churches within the Apostolic Faith Mission of South Africa. Cape Town, Bellville: University of the Western Cape.

Lebeloane, L. and Mokhele, M. 2006. The use of different types of water in the Zion Christian Church. Studia Historiae Ecclesiasticae XXXII(2): 143-152.

Masondo, S. 2013. The crisis model for managing change in African Christianity: The story of St John's Apostolic Church.Exchange 42(1): 157-174.

Matika, B.M. 2004. Religion and the advent of democracy in South Africa.MA Dissertation. Texas: Women's University.

Maxwell, D. 1999. Historicizing Christian independency: The Southern African Pentecostal Movement 1908 to 1960.Journal of African History 40(2): 243-264.

McDonnell, K. 1966. The ecumenical significance of the Pentecostal Movement. Worship 40(10): 608-629.

Moripe, S. 1996. The organisation and management of the Zion Christian Church, submitted in the fulfilment of the requirements for the degree of Doctor of Theology in the Department of Church History and Missiology, in the Faculty of Theology, University of Durban-Westville, Durban.

Nel, M. 2005. Dutch reformed missionary, Zionist preacher and leader of the Apostolic Faith Mission of South Africa, and the origin of some of African Independent Churches in Southern Africa.Studia Historiae Ecclesiasticae 31(1): 127-143.

Poloma, M. 2006. Old wine, new wineskins: The rise of healing rooms in revival Pentecostalism. Journal of the Society for Pentecostal Studies 28(1): 59-71.

Pillay, G.J. 1987. Pentecostalism with a South African community: The question of social change. Mission Studies 4(2): 39-51.

Poewe, K.O. 1988. Links and parallels between black and white charismatic churches in South Africa and the States: Potential for cultural transformation.Pneuma 10(2): 141-158.

Richardson, L.K. 2013. What has Pentecostalism to do with race relations? A study of the Apostolic Faith Mission in South Africa? Michigan:ProQuest.

Roy, K. 2000. Zion City RSA: The story of the church in South Africa. Pretoria: South African Baptist Historical Society.

Thomas, L.E. 1997. Survival and resistance in an African Indigenous church.Journal of Theology for Southern Africa 98(1): 13-20.

Thomas, L.E. 1999. Under the canopy: Ritual process and spiritual resilience in South Africa. Columbia, South Carolina: University of South Carolina. 